[Radiocarbon, Vol 23, No. 1, 1981, P 14-23]

\title{
BRITISH MUSEUM NATURAL RADIOCARBON MEASUREMENTS XII
}

\section{RICHARD BURLEIGH, KEITH MATTHEWS, JANET AMBERS}

Research Laboratory, The British Museum, London

WC1B 3DG, England

and IAN KINNES

Department of Prehistoric and Romano-British Antiquities, The British Museum, London WC1B 3DG, England

The following list consists entirely of dates for archaeologic samples from the British Isles, mainly measured over the period from May 1979 to June $1980^{1}$. The dates were obtained by liquid scintillation counting of benzene using the laboratory procedures outlined in previous lists (see, eg, BM-VIII, R, 1976, v 18, p 16).

The dates are expressed in radiocarbon years relative to AD 1950 based on the Libby half-life for ${ }^{1+} \mathrm{C}$ of $5570 \mathrm{yr}$, and are corrected for isotopic fractionation $\left(\delta^{13} \mathrm{C}\right.$ values are relative to $\left.\mathrm{PDB}\right)$. No corrections have been made for natural ${ }^{14} \mathrm{C}$ variations. The modern reference standard is NBS oxalic acid. Errors quoted with the dates are based on counting statistics alone and are equivalent to \pm 1 standard deviation $( \pm 1 \sigma)$.

Descriptions, comments, and references to publications are based on information supplied by the persons who submitted the samples.

The results published here represent the first stage of a research program devoted to the British Bronze age, initiated in 1979. This program derived from a growing awareness that traditional chronologic schemes were coming increasingly under attack, and that the existing framework provided by radiocarbon dates was insufficient as it was of sporadic coverage and depended heavily upon single determinations. At the same time, renewed activity in the excavation of settlement sites provided an ideal opportunity for the collection of multiple stratified samples.

The criteria adopted for selection of samples for the program were as follows:

1. Multiple samples chosen from recent excavations to demonstrate stratified sequences; where possible two or more samples from the same context were dated for added confidence (eg, Aldermaston Wharf, Billingborough Fen).

2. Smaller series, in some instances only single samples, chosen from secure contexts to fill lacunae or develop regional sequences (eg, Barling, Handley Barrow 24).

3. Emphasis laid throughout on security of context and nature of sample in relation to processes of site formation. Material that could be

${ }^{1}$ Dates obtained over the same period for other, unrelated, samples will form a separate list, BM-XIV. 
related to a specific event was preferred to that from only a generalized context.

4. Preference given to samples associated with distinctive artifact assemblages.

There are few surprises in this date list in light of evolving concepts of British Bronze age chronology. Perhaps the most significant result is evidence for distinct regional processes. This can be seen most clearly in the later part of the period where contiguous zones of the Thames Valley and the Wessex chalk uplands stand in sharp contrast. In the latter area, settlements and cemeteries with Deverel-Rimbury wares continue well into the lst millennium $\mathrm{bc}^{2}$, whilst in the former, this tradition was evidently replaced by an innovative and sharply contrasting series of pottery styles before that time ( $c f$ Handley Barrow 24, Knight's Farm). Comparable evidence for other areas is as yet only hinted at, but clearly one focus of attention for further dating must be finer resolution of the pattern of regional specialization.

From the results listed here it is evident that replacement of "traditional" chronologic methods (typology and closed associations) by a framework for the British Bronze age based on radiocarbon dates would be premature. The determinations from several settlement sites, notably the Holne Moor sequence (BM-1607, -1608, -1610, -1611, -1612), suggest that even when dates form a cluster this is likely to bracket two centuries or so and that finer chronology must continue to depend, for the time being at least, on observed stratigraphies.

ACKNOWLEDGMENTS

I K thanks J Barrett, R Bradley, I H Longworth, and S Needham for informative discussions.

\section{SAMPLE DESCRIPTIONS \\ ARCHAEOLOGIC SAMPLES}

\section{A. British Isles}

\section{Billingborough Fen, Lincolnshire}

Charcoal samples from Bronze age settlement (Chowne, 1978) at Billingborough Fen, Sleaford, Lincolnshire, England $\left(52^{\circ} 55^{\prime} \mathrm{N}, 0^{\circ} 20^{\prime}\right.$ W, Natl Grid Ref TF 126334). Coll 1977-1978 and subm by P Chowne, $S$ Lincs Archaeol Unit.

\section{BM-1410. Billingborough Fen} ditch.

Sample BFE77F10d from primary silting of $\mathrm{N}$ side of main enclosure

\footnotetext{
BM-1411. Billingborough Fen

$3430 \pm 110$

$\delta^{13} \mathrm{C}=-24.3 \%$ ditch.

Sample BFE77F43c from primary silting of $\mathrm{E}$ side of main enclosure
}

${ }^{2}$ British convention for uncorrected radiocarbon dates in the Christian calendar. 
BM-1429. Billingborough Fen

$$
2210 \pm 40
$$

Sample BFE78.4 from top layer of Middle Bronze age enclosure ditch, overlying bank material and assoc with Late Bronze age pottery group.

\section{BM-1430. Billingborough Fen}

$$
2800 \pm 60
$$

Sample BFE78.164 from secondary silt of main enclosure ditch.

General Comment $(\mathrm{PC})$ : dates compare favorably with site stratigraphy and phasing suggested by Chowne (1979).

\section{Itford Bottom, Sussex}

Charcoal samples from trench in dry valley at Itford Bottom, Beddingham, Lewes, E Sussex, England $\left(50^{\circ} 50^{\prime} \mathrm{N}, 0^{\circ} 0^{\prime} \mathrm{E}\right.$, Natl Grid Ref TQ 441049) assoc with possible Bronze age land clearance. Coll 1978 and subm by M Bell, Dept Human Environment, Inst Archaeol, Univ London.

\section{BM-1544. Itford Bottom}

$$
8770 \pm 90
$$

Sample IB $/ \mathrm{B} / \mathrm{SH} / 1$ (Pinus sp, id by Joan Sheldon) from fossil tree hole sealed by Bronze age plough-wash. Comment (MB): gives Boreal date for closed woodland conditions indicated by terrestrial Mollusca from feature, but some sp present indicate later date (M P Kerney, pers commun).

\section{BM-1545. Itford Bottom}

Sample IB/B/2 (various sp, mainly Quercus, Corylus, Fraxinus, and Crataegus, id by Joan Sheldon) from basal horizon of truncated buried soil containing Middle Bronze age pottery. Comment (MB): charcoal probably represents scrub clearance followed by cultivation. Early Bronze age date is perfectly acceptable for burning of secondary scrub.

\section{Aldermaston Wharf, Berkshire}

Samples from Bronze age settlement site at Aldermaston Wharf, $2 \mathrm{~km}$ SE Beenham, Berkshire, England $\left(51^{\circ} 25^{\prime} \mathrm{N}, 1^{\circ} 10^{\prime} \mathrm{W}\right.$, Natl Grid Ref SU 607678). Site on Kennet gravels $7 \mathrm{~km}$ W Knight's Farm, below. Assoc pottery sequence suggests single short occupation overlapping part of Knight's Farm sequence. Coll 1976 and subm by R J Bradley, Dept Archaeol, Univ Reading.

\section{BM-1590. Aldermaston Wharf}

$$
\begin{array}{r}
\mathbf{3 0 0 0} \pm \mathbf{4 0} \\
\delta^{13} \mathrm{C}=-22.8 \% \text { o }
\end{array}
$$

Sample 1, Pit 68. Carbonized grain (barley and emmer wheat, id by J Arthur) from extensive deposit on base of pit directly sealed by single deposit of midden material, assoc with coarse post-Deverel-Rimbury jars and finer bowls. 
BM-1591. Aldermaston Wharf

Sample 2, Pit 68. Repeat of BM-1590 above, different sample.

\section{BM-1592. Aldermaston Wharf}

$3240 \pm 140$

$\delta^{13} \mathrm{C}=-24.2 \%$

Sample 3, Pit 6. Charcoal from lower fill of rapidly accumulated midden deposit, assoc with range of diagnostic pottery types.

General Comment (RJB): pottery from this single-period site suggests date is in early 1st millennium bc and dates generally agree. BM-1592 is surprisingly early, but at $2 \sigma$, would be consistent with BM-1590 in suggesting some use of site by end of 2nd millennium bc. BM-1590, -1591 do not overlap at $1 \sigma$, but do bracket suggested time of occupation based on pottery. These dates refer to post-Deverel-Rimbury phase and are consistent with other dates from region, at Knight's Farm (BM-1593 to BM-1597, below) and Rams Hill (HAR-228 to HAR-232, R, 1974, v 16, p 182).

\section{Knight's Farm, Berkshire}

Charcoal samples from Bronze age settlement site Knight's Farm, Burghfield, Berkshire, England $\left(51^{\circ} 30^{\prime} \mathrm{N}, 1^{\circ} 0^{\prime} \mathrm{W}\right.$, Natl Grid Ref SU 679702). Site on Kennet gravels $7 \mathrm{~km} \mathrm{E}$ Aldermaston Wharf was occupied continuously from late Middle Bronze age to Late Bronze age/Early Iron age transition. Coll 1977 by S Lobb and subm by R J Bradley.

\section{BM-1593. Knight's Farm}

$\mathbf{3 6 3 0} \pm \mathbf{5 0}$

Sample KF77 / 86 from fill of possible oven.

$$
\delta^{13} \mathrm{C}=-24.8 \% \text { o }
$$

\section{BM-1594. Knight's Farm}

$$
\begin{array}{r}
\mathbf{3 2 0 0} \pm \mathbf{1 0 0} \\
\delta^{13} \mathrm{C}=-24.7 \%
\end{array}
$$

Sample KF77/103 from homogeneous fill of large rubbish pit accumulated over short period, assoc with late Deverel-Rimbury pottery. Pit marks beginning of long settlement sequence.

\section{BM-1595. Knight's Farm}

$$
2240 \pm 120
$$$$
\delta^{13} \mathrm{C}=-23.1 \% \text { o }
$$

Sample KF77/106 from homogeneous fill of rubbish pit accumulated over short period, assoc with wide variety of unabraded pottery including angular finger-printed vessels. Pit marks end of long settlement sequence.

\section{BM-1596. Knight's Farm}

$2820 \pm 110$

Sample KF77/159 from fill of post-hole of large round-house belonging to distinctive type of Late Bronze age structure.

General Comment (RJB): dates refer to long Bronze age and Early Iron age occupation. BM-1593 is much earlier than any other date from site; this may result from burning of mature wood or feature may be unconnected with rest of site. Pottery sequence begins in Deverel-Rimbury phase and BM-1594 assoc with this material agrees with other dates for 
these wares (HAR-2754, $3060 \pm 100$; HAR-2929, $3150 \pm 100$, both unpub). BM-1596 compares with HAR-1011, $2690 \pm 80$ and HAR-1012, 2550 \pm 80 (both unpub). Overall, dates form internally consistent sequence and agree with those for Aldermaston Wharf (BM-1590 to BM-1592, above).

\section{Holne Moor, Devon}

Charcoal samples from multi-phase settlement site at Holne Moor Site F, Holne Moor, Holne, Devon, England $\left(50^{\circ} 30^{\prime} \mathrm{N}, 3^{\circ} 50^{\prime} \mathrm{W}\right.$, Natl Grid Ref SX 678711). Coll 1977 and subm by A Fleming, Dept Prehist \& Archaeol, Univ Sheffield (Fleming, 1976).

\section{BM-1604. Holne Moor}

Sample XA from below wall of House 1.

\section{BM-1605. Holne Moor}

Sample XB from outside entrance to House 1.

\section{BM-1606. Holne Moor}

Sample XC from upper fill of House 1 ditch.

\section{BM-1607. Holne Moor}

Sample XD from floor of House 2.

\section{BM-1608. Holne Moor}

Sample XE from doorway of House 2, sealed by debris.

\section{BM-1609. Holne Moor}

Sample XF from top $10 \mathrm{~cm}$ of pre-reave bank.

\section{BM-1610. Holne Moor}

Sample XG sealed by N wall of House 2 .

\section{BM-1611. Holne Moor}

Sample XK sealed by wall of House 2 .

\section{BM-1612. Holne Moor}

$$
\begin{array}{r}
\mathbf{6 7 6 0} \pm \mathbf{2 4 0} \\
\delta^{13} C=-24.8 \%
\end{array}
$$

$$
1000 \pm 60
$$$$
\delta^{13} C=-25.1 \%
$$

$$
4730 \pm 360
$$$$
\delta^{13} C=-24.5 \%
$$

$$
3250 \pm 50
$$

$\delta^{13} C=-24.6 \%$

$$
3060 \pm 50
$$

$\delta^{13} C=-24.2 \%$

$$
\begin{array}{r}
\mathbf{3 2 7 0} \pm \mathbf{6 0} \\
\delta^{13} C=-24.6 \% \text { o }
\end{array}
$$

$$
\begin{array}{r}
\mathbf{3 1 5 0} \pm \mathbf{8 0} \\
\delta^{1 s} C=-24.3 \% \text { o }
\end{array}
$$

$$
\begin{array}{r}
\mathbf{3 1 5 0} \pm \mathbf{8 0} \\
\delta^{13} C=-24.2 \%
\end{array}
$$

$$
2490 \pm 110
$$$$
\delta^{13} \mathrm{C}=-24.1 \%
$$

Sample XL from inner edge of wall of House 1, sealed by House 2. General Comment (AF): BM-1607 to BM-1611 fully agree with archaeol expectations. BM-1609 should date initial layout of Dartmeet parallel system and implies dates for House $O$ (for outline of sequence, see Fleming, 1979). Other four dates in this group relate to occupation of House 1 (sample descriptions for BM-1607, -1608 do not contradict this statement as House 2 was built inside House 1 without stratigraphically distinct floor levels). BM-1612 should date building of House 2, but supporting evidence is awaited. BM-1604 is much earlier than expected and could relate to natural fire or Mesolithic occupation (two microliths 
were found within $20 \mathrm{~m}$ ). BM-1605 was a composite sample and could be mix of prehistoric and Medieval material (ca AD 1300). BM-1606 is ca 2000 yr earlier than expected.

\section{Petters Sports Field, Egham, Surrey}

Charcoal samples from Late Bronze age enclosure at Petters Sports Field, The Avenue, Egham, Surrey, England $\left(51^{\circ} 30^{\prime} \mathrm{N}, 0^{\circ} 35^{\prime} \mathrm{W}\right.$, Natl Grid Ref TQ 016715). BM-1620 to BM-1624 from final fill of enclosure ditch, BM-1625 from fill of pit within enclosure; samples date assoc pottery and bronze artifacts. Coll $1976-1977$ by R Poulton and subm by M G O'Connell, Surrey Archaeol Soc, Guildford.

BM-1620. Petters Sports Field Sample F117/Ia.

BM-1621. Petters Sports Field Sample F117/Ib.

\section{BM-1622. Petters Sports Field}

Sample F117/Ic. Fractionation correction estimated.

\section{BM-1623. Petters Sports Field} Sample F117/Id.

\section{BM-1624. Petters Sports Field} Sample F117/Ie.

\section{BM-1625. Petters Sports Field}

Sample F $405 / \mathrm{I} \alpha$.

$$
\begin{array}{r}
\mathbf{2 3 6 0} \pm \mathbf{9 0} \\
\delta^{13} C=-25.3 \% \\
\mathbf{2 3 6 0} \pm \mathbf{6 0} \\
\delta^{13} C=-24.2 \% \\
\mathbf{2 7 2 0} \pm \mathbf{1 1 0} \\
\delta^{13} C=-25.0 \%
\end{array}
$$

$$
2460 \pm 80
$$$$
\delta^{13} C=-24.4 \% \text { 。 }
$$$$
\begin{array}{r}
\mathbf{2 4 5 0} \pm \mathbf{7 0} \\
\delta^{13} C=-24.1 \% 0
\end{array}
$$$$
2670 \pm 90
$$

$\delta^{13} C=-24.2 \%$

General Comment (SN): BM-1620, to BM-1624 relate to same context containing large group of Late Bronze age/Early Iron age pottery; they are later than expected for these wares, but are internally consistent. Results should date uppermost ditch fill sealing horizon into which double-hoard dated traditionally to 8 th or early 7 th centuries BC, had been inserted. BM-1625 dates separate pit and suggests earlier settlement activity more in line with dates so far obtained for occupation at Runnymede Bridge $400 \mathrm{~m}$ away. BM-1622 may also derive from this phase of activity and be residual in context.

\section{BM-1631. Barling, Essex}

$3290 \pm 90$

$\delta^{13} C=-24.1 \%$

Charcoal from Baldwin's Farm Gravel Pit, Barling, Essex, England $\left(51^{\circ} 35^{\prime} \mathrm{N}, 0^{\circ} 50^{\prime} \mathrm{E}\right.$, Natl Grid Ref TQ 937896). From small pit assoc with Deverel-Rimbury bucket urn sherds. Coll 1977 and subm by $\mathrm{C}$ Couchman, Essex Co Council Planning Dept, Chelmsford. Comment (IK): date is appropriate to regional "Deverel-Rimbury" aspect of later Bronze age on current evidence. 
BM-1632. Braintree, Essex

$$
\mathbf{2 7 8 0} \pm 35
$$

Charcoal from base of pit at Marlborough $\mathrm{Rd}, \mathrm{Br}$ intre, Ess England $\left(51^{\circ} 55^{\prime} \mathrm{N}, 0^{\circ} 30^{\prime} \mathrm{E}\right.$, Natl Grid Ref $\mathrm{TL}$ 769238) assoc with Middle Bronze age pottery. Coll 1977 and subm by C Couchman. Comment (IK): date is appropriate to regional "Deverel-Rimbury" aspect of later Bronze age on current evidence.

\section{BM-1640. Nottington Barrow, Dorset \\ $3140 \pm 45$}

Charcoal (mature pine) from Nottington Barrow, Weycul, set, England (50 $35^{\prime} \mathrm{N}, 2^{\circ} 30^{\prime} \mathrm{W}$, Natl Grid Ref SY 667825). Sample from funeral pyre in mound assoc with cremation burial and Wessex I 3-riveted dagger (Farrar, 1951). Coll 1938 by K Selby and subm 1978 by R T Schadla-Hall, Hampshire Co Mus Service, Winchester. Comment (IK): date agrees well with those for other "Wessex" burials, which cluster in 13th to 11th centuries bc (BM-680, -681, -682, -708, -709: R, 1976, v 18, p 27, 30; BM-1119: R, 1979, v 21, p 344).

\section{BM-1643. Blackpatch, Sussex \\ $2790 \pm 40$}

Carbonized grain from patch, Alciston, E Sussex, England $\left(51^{\circ} 50^{\prime} \mathrm{N}, 1^{\circ} 10^{\prime} \mathrm{F}\right.$, Natl Grid Ref TQ 495047). Sample from base of 1 of 3 oval pits belonging to House 3 (Drewett et al, 1978). Coll 1978 and subm by P Drewett, Sussex Archaeol Field Unit. Comment (IK): date is later than expected for classic Deverel-Rimbury assemblage with assoc bronze, but falls within late Wessex regional aspect of culture ( $c f$ Bishop's Cannings, BM-1713 to BM-1717, below).

\section{Handley Barrow 24, Cranborne Chase, Dorset}

Charcoal samples from Middle Bronze age urnfield, Handley Barrow 24, Sixpenny Handley, Cranborne Chase, Dorset, England $\left(51^{\circ} 0^{\prime}\right.$ N, $1^{\circ} 50^{\prime}$ W, Natl Grid Ref SU 009165) assoc with varied and wellpreserved assemblage of Deverel-Rimbury wares, and with other Middle Bronze age activity in Cranborne Chase (Barrett et al, 1978; Pitt Rivers, 1898). Coll 1893 by A Pitt Rivers and subm 1978 by R J Bradley.

\section{BM-1644. Handley Barrow 24}

$2710 \pm 40$

Sample D, from compact charcoal patch at edge of cemetery, assoc with sherds of bucket urn.

\section{BM-1645. Handley Barrow 24}

$2840 \pm 35$

From fill of chalk-cut hole containin half of barrel urn, on outer edge of main group of cremations.

\section{BM-1646. Handley Barrow 24}

$2900 \pm 40$ main group of cremations, assoc with decorated sherd. 
BM-1647. Handley Barrow 24

$2820 \pm 40$

From fill of lower half of barrel urn, mixed with Cremation 32 situated on edge of main group of cremations.

BM-1648. Handley Barrow 24

$2810 \pm 60$

From fill of pit containing bucket or barrel urn holding Cremation 38 , situated in core of urnfield.

\section{BM-1649. Handley Barrow 24}

$$
2670 \pm 45
$$

From fill of pit containing bucket urn and Cremation 46 , on edse of cemetery close to presumed Early Bronze age burial which may be point of origin of urnfield.

General Comment (RJB): dates are remarkably consistent internally, particularly for samples coll in 19th century. Dates give broad time span of cremation cemetery, although no charcoal was assoc with single Collared Urn from site; latest dates (BM-1644, -1649) are from outer edge of cemetery. Dates suggest late extension to currency of DeverelRimbury pottery in S Wessex and help fill gap created by apparent rarity of post-Deverel-Rimbury types from area.

\section{Dean Bottom, Wiltshire}

Charcoal from multi-period Bronze age settlement at Dean Bottom, $5 \mathrm{~km}$ NW Marlborough, Wiltshire, England $\left(51^{\circ} 25^{\prime} \mathrm{N}, 1^{\circ} 50^{\prime} \mathrm{W}\right.$, Natl Grid Ref SU 147742). Samples assoc with assemblage of domestic Beaker pottery in fill of pit. Coll 1977 and subm by C J Gingell, Wilts Archaeol \& Nat Hist Soc, Devizes.

\section{BM-1668. Dean Bottom}

Sample 18 from middle layer of Beaker pit.

\section{BM-1669. Dean Bottom}

\section{Sample 19 from basal layer of Beaker pit.}

General Comment (CJG): dates are for characteristic Beaker period storage pit and confirm those obtained elsewhere for settlements assoc with Middle Beaker material. Rapid filling of pit is apparent from stratigraphy and large numbers of conjoining sherds and undamaged bones are present. Thus, no archaeol evidence for redeposition of either charcoal sample; difference between dates may be statistical, due to initial age of wood, or both.

\section{Welsh St Donats, S Glamorgan}

Charcoal samples (Quercus sp, id by G Hillman) from Bronze age round barrow, Welsh St Donats, S Glamorgan, Wales $\left(50^{\circ} 20^{\prime} \mathrm{N}, 3^{\circ} 20^{\prime}\right.$ W, Natl Grid Ref ST 041749). Coll 1977 and subm by J Price and M Ehrenberg, Dept Archaeol, Univ Coll, Cardiff (Price \& Ehrenberg, 1977). 


\section{BM-1679. Welsh St Donats}

$2810 \pm 35$

Sample WSD77/1 from fill of pit sealed under turf mound ar above central cremation assoc with bronze knife dagrer. Sample dates dagger and construction of mound.

\section{BM-1680. Welsh St Donats}

$3190 \pm 35$

$\delta^{13} \mathrm{C}=-25.2 \%$

Sample WSD77/2 from old ground surface ca $1 \mathrm{~m}$ from central burial and sealed by mound. Sample dates construction of turf mound.

\section{BM-1681. Welsh St Donats}

$3250 \pm 35$

Sample WSD77/3 surrounding one of pair of crouched inhumations, assoc with bronze awl and late Beaker, lying on old ground surface under low stone cairn and turf mound, $\mathrm{E}$ of central cremation.

General Comment (JP): BM-1679 is much later than expected from assoc knife dagger of Early Bronze age type, ca 1400 BC (1200 bc; 3150 вP). BM-1680 is consistent with BM-1681 which, though late, is acceptable for late Beaker vessel.

\section{Bishop's Cannings, Wiltshire}

Charcoal samples from Bronze age settlement at Bishop's Cannings Down, S Avebury, Wiltshire, England $\left(51^{\circ} 20^{\prime} \mathrm{N}, 2^{\circ} 0^{\prime} \mathrm{W}\right.$, Natl Grid Ref SU 058666). Coll 1976-1977 and subm by C J Gingell.

\section{BM-1713. Bishop's Cannings}

$$
2740 \pm 60
$$

$\delta^{13} \mathrm{C}=-23.8 \%$ o

Sample 43 from Layer 43, post-pipe of Feature 218, post-hole of House B, assoc with characteristic Bronze age pottery.

\section{BM-1714. Bishop's Cannings}

Sample 158 from Layer 158, S post-pipe of Feature 161, entrance to House $\mathrm{B}$.

\section{BM-1715. Bishop's Cannings}

$2860 \pm 40$

Sample 167 from Layer 167, post-pipe within Feature 177, House A.

\section{BM-1716. Bishop's Cannings}

$$
2830 \pm 100
$$

Sample 99 from Layer 99 within Feature 205, post-hole of House A.

\section{BM-1717. Bishop's Cannings}

$2790 \pm 50$

Samples 169, 174 from Layer 169, upper fill in entrance post-hole, Feature 187 to 189 , House A, and Layer 174, post position in Feature 188, House A entrance post-hole.

General Comment (CJG): dates obtained for these two Bronze age round-houses are satisfactory on archaeol grounds. Close assoc of pottery 
with samples and with houses in general emphasize survival of Bucket, Biconical, and Globular Urns, and in particular, Kimmeridgian shelltempered urns characteristic of this site, to end of Middle Bronze age and perhaps later.

\section{REFERENCES}

Barrett, J, Bradley, R, Cleal, R, and Pike, H, 1978, Characterization of Deverel-Rimbury pottery from Cranborne Chase: Prehist Soc Proc, v 44, p 135-142.

Chowne, P, 1978, Billingborough Bronze age settlement — an interim note: Lincolnshire Hist and Archaeol, v 13, p 15-20.

1979, Billingborough: Current Archaeol, no. 67, v 6, pt 8, p 246-248.

Drewett, P, Bedwin, O, Freke, D, and Rudling, D, 1978, Rescue archaeology in Sussex, 1977: Univ London Inst Archaeol Bull, no. 15, p 49-72.

Farrar, R, 1951, Archaeological fieldwork in Dorset in 1951: Dorset Nat Hist and Archaeol Soc Proc, v 73, p 85-115.

Fleming, A, 1976, The Dartmoor reaves: Current Archaeol, no. 55, v 5, pt 8, p 250-252. p 234-237.

Pitt Rivers, A, 1898, Excavations in Cranborne Chase, v 4: London, privately printed.

Price, J and Ehrenberg, M, 1977, Welsh St Donats: Morgannwg (Glamorgan Hist Jour), v 21, p 89-90. 